\title{
PART III: CONCEPTUALIZATIONS Models for Program Planning
}

In this section, we present a spectrum of articles illustrating professional and organizational development practice informed by the theory, research, and methodology of many disciplines. These articles share a theme that characterizes our organization as well as emerging thought in many of the disciplines from which we borrow: the value of collaborative action as a vehicle for improving teaching and enhancing program effectiveness.

We begin with John Bailiff and Susan Kahn's description of a system-level program designed to meet the needs of faculty in diverse institutions. Much of the program's success stems from its capacity to foster interinstitutional exchanges within a single state. Our second article, by Robert Menges, explores the potential for collaborative activity between faculty colleagues in the service of teaching improvement; this paper draws on staff development research in public schools as well as higher education literature. The collaborative theme continues in Elizabeth McDaniel's description of a program that engages faculty in a common search for characteristics of good teaching, then encourages them to help each other discover and develop those characteristics in their own work. Like teaching, professional writing is often through of as a solitary activity, one that is often assumed to be beyond the domain of faculty development programs. Challenging these assumptions, Bob Boice and Jim Turner describe how faculty developers can reduce the 
isolation of writing and help faculty become more productive scholars.

"Staying close to the customer" is the theme of the final two articles in this section. Many faculty development programs offer workshops as a major strategy for reaching faculty, but too often such workshops seem to reach only a select few who participate in anything and everything the office chooses to present. Reaching the less innovative, involved faculty member is the challenge tackled by Linda Hilsen, Rusty Wadsworth, and Judith Cohen. Their approach draws on marketing theory to insure a good fit between faculty needs and program offerings. Finally, we present Ann Ferren and Kay Mussell's description of a collaborative approach to evaluation of an entire faculty development program. Faculty participation in such an evaluation is consistent with current management theories that stress customer contact; it also provides a vehicle for faculty ownership of the program, since faculty participants interpret results and incorporate them into program planning. 